\title{
New dispersion-compensated Raman-amplifier cascade with a single-pump parametric amplifier for dense wavelength-division multiplexing
}

\author{
${ }^{1}$ Kaur G., ${ }^{2}$ Kaur Gurmeet and ${ }^{1}$ Sharma S. \\ ${ }^{1}$ ECED, Thapar Institute of Engineering \& Technology, Deemed University, Patiala, \\ India gaganpreet.kaur@thapar.edu, preetkgagan@gmail.com \\ ${ }^{2}$ ECE, Punjabi University Patiala, India
}

Received: 23.12 .2019

\begin{abstract}
In this work a dispersion-compensated Raman amplifier has been cascaded with a single-pump parametric amplifier to build a dense wavelengthdivision multiplexed (DWDM) system. This hybrid system demonstrates a flat gain in the L-band. Our hybrid has been evaluated for a $25 \mathrm{GHz} 96$-channel system at $40 \mathrm{Gbps}$ in the band spreading from 189 to $191.375 \mathrm{THz}$. The results demonstrate the gain larger than $16.9 \mathrm{~dB}$ and the gain ripple less than $5.82 \mathrm{~dB}$, with no gainflattening technique used. The novelty of our design lies in combining dispersion compensation with signal amplification in a long-length Raman-amplifier fibre followed by a short-length parametric amplifier implemented on a separate highly nonlinear fibre. For the data rate $10 \mathrm{Gbps}$, the achievable gain ripple is as low as $1.9 \mathrm{~dB}$, without any gain-compensation technique. The optical signal-to-noise ratio larger than $18 \mathrm{~dB}$ and the flat gain confirm that our Raman fibre-optic parametric amplifier can be used as a tunable and broad-gain amplifier for the future long-haul DWDM systems. The results obtained for our system have been compared with those of the L-band optical amplifiers developed recently. The comparison testifies that our amplifier is the best of all existing analogues.
\end{abstract}

Keywords: dense wavelength-division multiplexing, parametric amplifiers, Raman fibre-optic parametric amplifiers, gain, gain flatness, optical signal-to-noise ratio

UDC: $535+681.7 .068$

\section{Introduction}

Optical amplifiers are key devices in implementing long-haul optical transmission systems. In the recent years, fibre-optic parametric amplifiers (FOPAs) have attracted considerable attention of researchers. They are suitable for wavelength-division multiplexing systems due to their broadband properties and relatively low-noise amplification [1-3]. The FOPAs are based on the nonlinear phenomena of four-wave mixing (FWM). Using the FWM, one can transfer energy from strong fields to weak signals, thus amplifying the latter. Application of FOPAs in the contemporary wavelength-division multiplexing systems has increased considerably with advent of highly nonlinear fibres and polycrystalline fibres [3]. Feasibility of broadband and long-haul dense wavelength-division multiplexing (DWDM) systems based on the FOPAs has been demonstrated for the case of $50 \mathrm{GHz}$-spaced systems [4]. Although the FOPAs have their inherent advantage of wide gain bandwidth and are flexible in choosing the gain region via varying pump wavelengths, they offer a low gain, particularly if the number of channels is large. To increase the gain, hybrid FOPAs have been proposed [5-7]. A hybrid of FOPA with an erbium-doped fibre amplifier (EDFA) reduces the FWM crosstalk and leads to good gains [7]. However, the use of booster EDFAs limits the possibilities of wavelength selection in a parametric pump. 
Fibre Raman amplifiers represent another class of optical amplifiers which have recently attained great significance because of their distributed amplification over extended bandwidths. Wide amplification bandwidths $(>100 \mathrm{~nm})$ with low gain ripple $(<1.5 \mathrm{~dB})$ have been achieved using multi-pump configurations for the DWDM applications [8]. Over the last decade, Raman amplification has significantly evolved in the DWDM systems. So, Raman-assisted FOPAs have attracted considerable attention among the FOPA hybrids because of their flexibility in the selection of parametric-pump powers [9] and a broadband amplification.

Wang et al. [10] have proposed a hybrid amplifier comprising a Raman-assisted FOPA followed by a FOPA. They have demonstrated numerically a $70 \mathrm{~dB}$ peak small-signal gain for $1 \mathrm{~km}$ of highly nonlinear optical fibre (HNLF) with $1.5 \mathrm{~W}$ Raman and $0.2 \mathrm{~W}$ parametric pumps for an 8-channel DWDM system. This yields in the gain enhancement $34 \mathrm{~dB}$ if compared to a conventional Raman-assisted FOPA at the same parametric-pump powers. Peiris et al. [11] have demonstrated a hybrid Raman-optical parametric amplifier in a tandem configuration for extended bandwidth, with the gain more than $20 \mathrm{~dB}$, the extended gain bandwidth $170 \mathrm{~nm}$ and the gain ripple less than $4 \mathrm{~dB}$. Kaur et al. [12] have suggested a wide-gain amplifier using a Raman amplifier cascaded with a multi-section FOPA, thus achieving the flat gain $24.3 \mathrm{~dB}$ over the $220 \mathrm{~nm}$ bandwidth. In Ref. [13], an improved performance with a Raman-assisted FOPA has been achieved for the wavelength-division multiplexing system, with the net gain $20 \mathrm{~dB}$ and the gain ripple $1.9 \mathrm{~dB}$ for the 10 - and $100 \mathrm{GHz}$-spaced distributed-feedback lasers.

Ummy et al. [14] have achieved the extended flat gain about $15 \mathrm{~dB}$ with the gain ripple $5 \mathrm{~dB}$, using combined Raman and parametric interactions in an HNLF. The present authors in their works $[15,16]$ have used a Raman-FOPA hybrid cascade for flat gaining in a narrow-spaced $25 \mathrm{GHz}$ system and emphasized a feasibility of this hybrid for the long-distance transmission. However, no dispersion compensation has been employed, which makes achievement of sufficient Q-factor a challenge in such a densely spaced system. Besides, more Raman pumps have been explored in the previous work [15]. This provides higher gains but the pump-pump noise poses a challenge when achieving a flat gain and high enough Q-factor [16].

In this report, we suggest a new Raman-FOPA hybrid. Unlike any configuration discussed previously, dispersion compensation in our system is combined with a long-length Raman amplifier. The output is then launched into an HNLF for parametric amplification. The results are analyzed for the case of L-band amplification in a non-return-to-zero DWDM system. The numbers of Raman pumps and their powers have been optimized to ensure the best final results. The results obtained have been evaluated in terms of eye diagrams, gain flatness, Q-factor, bit error rate and dispersion for the cases of 10-, 16-, 32- and 96-channel systems.

\section{Simulation setup}

We simulate a DWDM system with 96 equally spaced channels in the L-band from 189 to 191.375 THz with the non-return-to-zero $40 \mathrm{Gbps}-$ modulated signal and the channel spacing $25 \mathrm{GHz}$ in order to analyze the performance of our Raman-FOPA cascade configuration. Fig. 1 shows the setup under analysis. In the given model, the Raman-FOPA hybrid serves as inline amplifier and a signal traverses $75 \mathrm{~km}$ span of a single-mode fibre before it is amplified. The Raman-FOPA hybrid comprises a Raman amplifier with three pumps from 1470-1505 nm and the pump power $650 \mathrm{~mW}$ for each pump. The Raman-amplified signal is then fed to a $200 \mathrm{~m} \mathrm{HNLF}$ section with the attenuation $\alpha=0.8 \mathrm{~dB} / \mathrm{km}$, the zero-dispersion wavelength located at $1578.4 \mathrm{~nm}$, the dispersion $0.2 \mathrm{ps} \mathrm{nm}^{-1} \mathrm{~km}^{-1}$, the dispersion slope $0.025 \mathrm{ps} /\left(\mathrm{nm}^{2} \mathrm{~km}\right)$, and the parametric pump 
operating at $\lambda_{p}=1586.203 \mathrm{~nm}$, which has the power $27 \mathrm{dBm}$. Note that, in the model proposed by us, the polarization states of the input and the pumps is assumed to be aligned with each other, which can sometimes be not true in a practice.

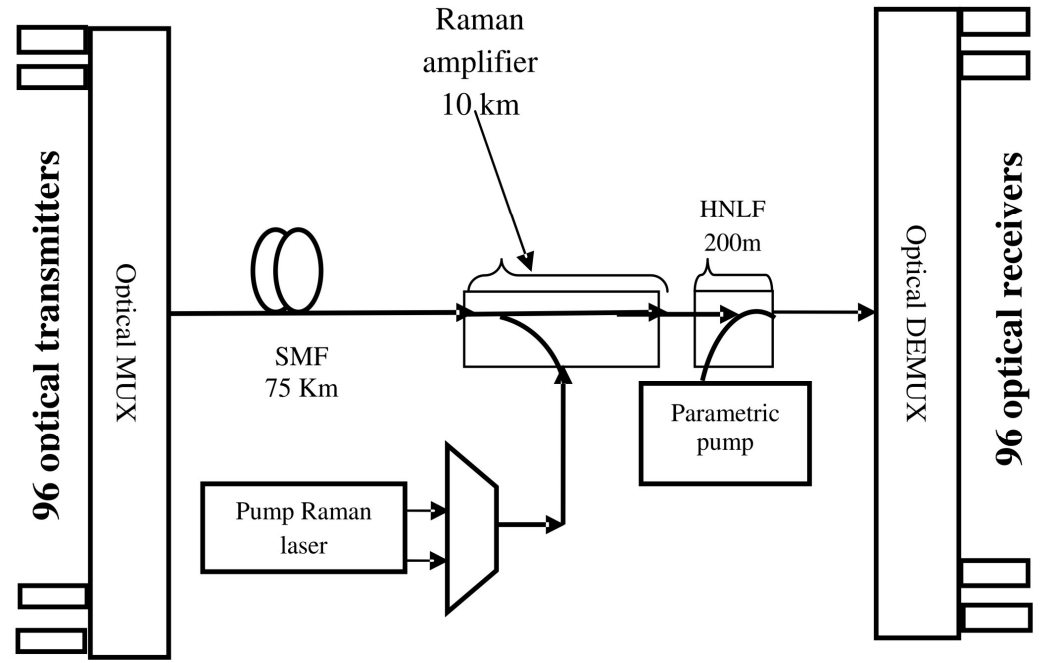

Fig. 1. A scheme of 96-channel DWDM system based on a Raman-FOPA hybrid amplifier.

The HNLF parameters used in our simulations are listed in Table 1 . The novelty of our design lies in implementing dispersion compensation in a Raman fibre itself, which is characterized by the dispersion $90 \mathrm{ps} \mathrm{nm}^{-1} \mathrm{~km}^{-1}$ and the dispersion slope $0.112 \mathrm{ps} / \mathrm{nm}^{2} / \mathrm{km}$. Here the fibre attenuation and the effective area are equal respectively to $0.5 \mathrm{~dB} / \mathrm{km}$ and $30 \mu \mathrm{m}^{2}$. Our interest to the above hybrid has been motivated by effective dispersion compensation achieved while combining amplification and dispersion compensation in the same length of fibre [17, 18]. The dispersion-compensating fibre in this case offers a net gain, thus leading to a wider system margin.

Table 1. HNLF parameters used in our parametric amplifier.

\begin{tabular}{cc}
\hline Parameter of HNLF & Value \\
\hline Dispersion slope & $0.02 \mathrm{ps} / \mathrm{nm}^{2} \mathrm{~km}$ \\
HNLF coefficient & $10(\mathrm{~W} \mathrm{~km})^{-1}$ \\
Length & $200 \mathrm{~m} \mathrm{(FOPA})$ \\
Attenuation & $0.8 \mathrm{~dB} / \mathrm{km}$ \\
\hline
\end{tabular}

In our Raman-FOPA model, the Raman amplifier is cascaded directly with the FOPA as shown in Fig. 1. For the single-pump Raman amplifier, the signal evolves as [19]

$$
s=-\alpha P_{S}+\left(\frac{g_{R}\left(v_{1}\right)}{A_{e f f}}\right) P_{R} P_{S} .
$$

Here $s$ is the evolving signal given by $d P_{S} / d z$, with $z$ denoting the direction of propagation of the signal. For the multi-pump configuration, the effect of signal pump gains is additive [20]. The Raman gain depends on the frequency $v_{1}$ and the pump power $P_{R}$. Assume that the gain of the Raman amplifier is as follows [19]:

$$
G_{\text {Raman }}=10 \log _{10}\left(\exp \left(g_{R} P_{R} L_{\text {eff }} / A_{\text {eff }}\right)-\alpha L\right),
$$

where $g_{R}$ is the Raman gain coefficient, $P_{R}$ the pump power, $L_{\text {eff }}$ the effective fibre length in the 
Raman amplifier, $L$ the actual length, $A_{\text {eff }}$ the effective fibre area, and $\alpha$ the fibre attenuation. After Raman gaining, the signal passes through the HNLF and experiences a parametric gain. Under a single parametric pump, the signal evolves according to (see Ref. [21])

$$
\frac{d A_{S}}{d z}=-\frac{1}{2} \alpha H_{S}+j 2 \gamma\left\{2 P A_{S}+P e^{-j \theta} A_{i}\right\},
$$

where $\theta$ is defined as $\theta=\{\beta-6 \gamma P\} z, \Delta \beta$ implies the wave-vector phase mismatch, $\gamma$ the nonlinear parameter of the HNLF, $P$ the parametric-pump power, $\alpha_{H}$ the attenuation of the HNLF, $A_{S}$ the signal entering the HNLF for parametric amplification, and $A_{i}$ the idler signal. Again, we stress that the effect of signal pump gains is additive in the multi-pump configuration [20]. So, considering three Raman pumps $P_{1}, P_{2}$ and $P_{3}$, we obtain the following signal entering the parametric amplifier:

$$
s=-\alpha P_{S}+\left(\frac{g_{R}\left(v_{1}\right)}{A_{e f f}}\right) P_{1} P_{S}+\left(\frac{g_{R}\left(v_{2}\right)}{A_{\text {eff }}}\right) P_{2} P_{S}+\left(\frac{g_{R}\left(v_{3}\right)}{A_{\text {eff }}}\right) P_{3} P_{S} .
$$

The expected gain of our Raman-FOPA hybrid then reads as

$$
G_{\text {hybrid }}=G_{\text {Raman }}+G_{F O P A} \text {. }
$$

Here we assume that both the Raman and FOPA gains are in decibels, whereas the gain $G_{\text {hybrid }}$ for our Raman-FOPA and the parameter $G_{F O P A}$ are given in Ref. [22]. If the gain of the hybrid is not in decibel units, it can be obtained by multiplying the individual gains of the cascaded amplifier.

We propose the Raman-FOPA cascade instead of a conventional Raman-assisted amplifier for the following reasons: (1) it allows the pumps for the Raman and FOPA components to be independently tuned in the complementary regions; (2) the Raman fibre requires longer lengths while the parametric amplifiers employ shorter-length HNLFs. Our design exploits the amplifying capabilities of each of the Raman and FOPA components, using separate fibres; (3) the Raman fibre is utilized for both amplification and dispersion compensation; and (4) the amplified output of the Raman amplifier serves as input for the FOPA. This increases signal power at its input and ensures a better FWM efficiency responsible for parametric amplification.

\section{Results and discussion}

Currently, the DWDM systems with the channel spacing of up to $50 \mathrm{GHz}$ are being deployed at the data rates higher than $40 \mathrm{Gbps}$. The channel spacing less than $50 \mathrm{GHz}$ is still a challenge due to increased nonlinearity and dispersion effects, particularly at high input powers. The optical systems with the transmission rates higher than $40 \mathrm{Gbps}$ have been an active area of recent research. For instance, Wen et al. [23] have investigated a $53.2 \mathrm{Gbps}$ non-return-to-zero system for $400 \mathrm{GbE}$. As we increase the data rate, a suitability of simple modulation formats such as nonreturn-to-zero is under doubt due to increased inter-symbol interference resulting from the increased dispersion. Rather new modulation formats have been suggested over the time, which accommodate more bits per symbol [24]. These systems require coherent detection systems [2527 at the receiver end, resulting in increased hardware and receiver complexity.

In this section we first analyze the effect of combining dispersion compensation with Raman amplification. We study the $40 \mathrm{Gbps}$ system with $25 \mathrm{GHz}$ channel spacing and 10 channels. After that, 16-, 32- and 96-channel systems are investigated. As seen from Fig. 2a and Fig. 2b, the eye diagrams become asymmetric as the channel spacing decreases from $50 \mathrm{GHz}$ to $25 \mathrm{GHz}$. This 
asymmetry points to amplitude distortion in the received signal. Fig. 3a demonstrates that the eye shape gets distorted at $50 \mathrm{GHz}$ as the number of channels increases. The distortion increases as the number of channels increases up to 32 and 96 (see Fig. 4a and Fig. 5a, respectively).
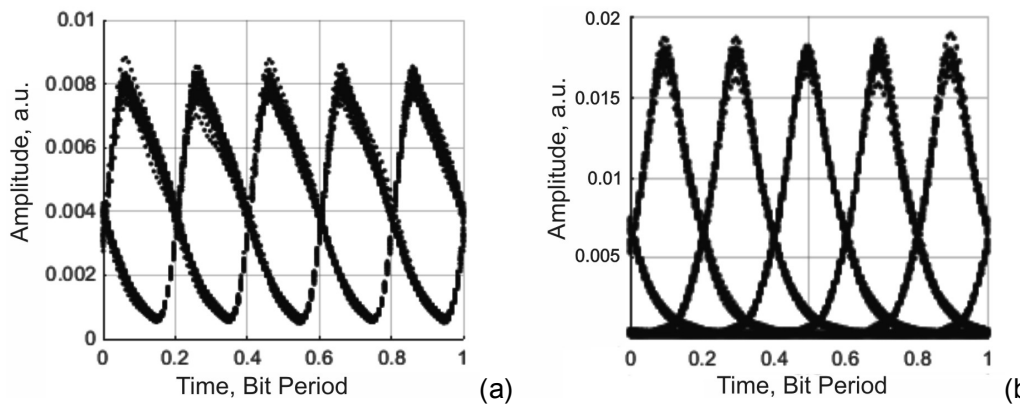

Fig. 2. Eye diagram for a 10 -channel system working at $40 \mathrm{Gbps}$ : spacing between channels is equal to $50 \mathrm{GHz}$ (a) and $25 \mathrm{GHz}$ (b).
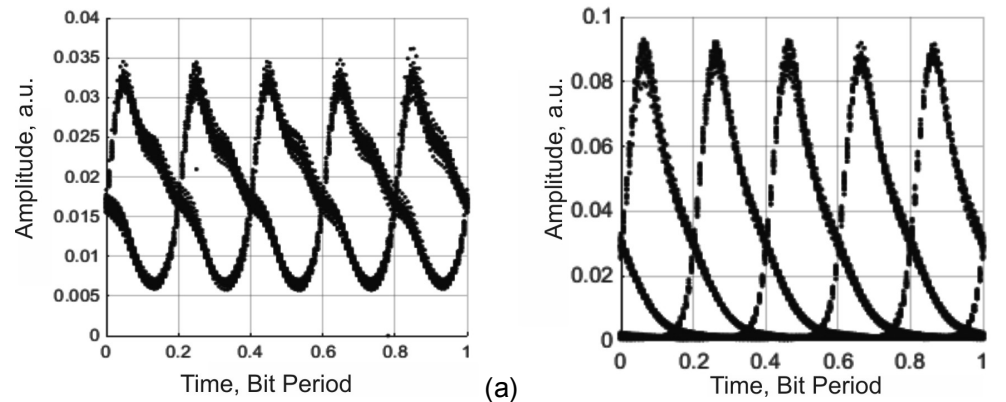

(b)

Fig. 3. Eye diagram for a 16 -channel system working at $40 \mathrm{Gbps}$ : spacing between channels is equal to $50 \mathrm{GHz}$ (a) and $25 \mathrm{GHz}$ (b).
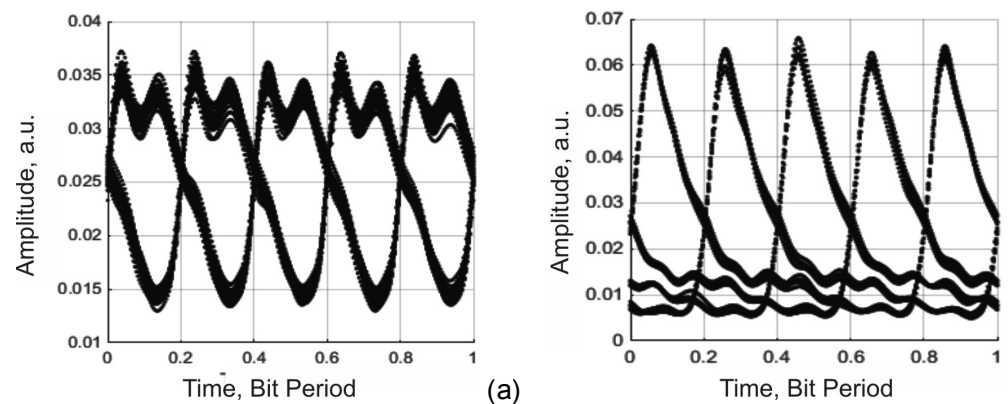

(a)

Fig. 4. Eye diagram for a 32 -channel system working at $40 \mathrm{Gbps}$ : spacing between channels is equal to $50 \mathrm{GHz}$ (a) and $25 \mathrm{GHz}(\mathrm{b})$.
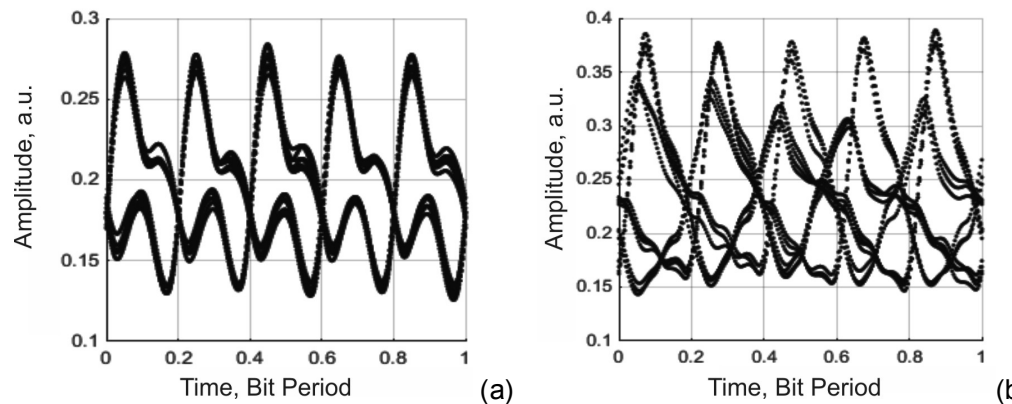

Fig. 5. Eye diagram for a 96 -channel system working at $40 \mathrm{Gbps}$ : spacing between channels is equal to $50 \mathrm{GHz}$ (a) and $25 \mathrm{GHz}$ (b).

Ukr. J. Phys. Opt. 2020, Volume 21, Issue 1 
Similar observations can be made with increasing number of channels for the $25 \mathrm{GHz}$ system (see Fig. 2b to Fig. 5b). The asymmetry increases if we pass from $50 \mathrm{GHz}$ to $25 \mathrm{GHz}$ systems. A shift in the crossing point of the eye diagram towards lower limits indicates that the amplitude distortion is much greater in the detection of amplitude corresponding to the bit ' 1 ', if compared to that of the bit ' 0 '. However, for the $25 \mathrm{GHz} 96$-channel system (see Fig. 5b) we observe increased jitter and a duty-cycle distortion increase for the both amplitude levels of ' 1 ' and ' 0 '. This implies that increased FWM gives rise to idlers which fall on signal-transmission frequencies, thus making filtering of the noise/idlers inefficient.

The bit error rate and the Q-factor found in our system for different channel numbers are displayed in Table 2. As seen from the eye-diagram analysis, the Q-factor falls with increasing number of channels and decreasing channel spacing. In spite of this decrease in the Q-factor, the Q-factor of more than 6 is achieved in our system with decreasing channel spacing and increasing channel number. Notice that this is attained with no gain-compensating technique used. The above fact testifies a very high efficiency of our hybrid parametric amplifier for narrow-spaced terabitcapacity DWDM systems.

Table 2. Bit error rate and Q-factor achieved for our $40 \mathrm{Gbps}$ system with dispersion compensation.

\begin{tabular}{ccc|ccc}
\hline \multicolumn{2}{c}{$50 \mathrm{GHz}$} & \multicolumn{3}{c}{$25 \mathrm{GHz}$} \\
\hline $\begin{array}{c}\text { Number of } \\
\text { channels }\end{array}$ & Q-factor & Bit error rate & $\begin{array}{c}\text { Number of } \\
\text { channels }\end{array}$ & Q-factor & Bit error rate \\
\hline 10 & 23.8477 & $4.89 \times 10^{-126}$ & 10 & 16.7883 & $1.1089 \times 10^{-63}$ \\
16 & 19.79 & $1.58 \times 10^{-86}$ & 16 & 16.3025 & $1.4716 \times 10^{-60}$ \\
32 & 17.3441 & $8.167 \times 10^{-67}$ & 32 & 10.9396 & $2.94 \times 10^{-28}$ \\
96 & 16.13 & $7.2978 \times 10^{-59}$ & 96 & 6.1588 & $3.664 \times 10^{-10}$ \\
\hline
\end{tabular}

The analysis of data shown in Table 2 and Table 3 demonstrates that the Q-factor falls down as we increase the number of channels. The dispersion and the FWM are both responsible for this Q-factor decrease. It becomes dominating in the 16-channel system as the dispersion increases. The FWM is also expected to increase with increasing number of channels. However, the dispersion dominates in the case of 16 channels, where the FWM becomes relatively weak. This arises since different group velocities due to dispersion make the FWM effect weak. Since the non-return-to-zero signals are used in transmission, the effect of nonlinearities, especially the FWM in the $25 \mathrm{GHz}$-spaced system, is dominant beyond the system of 16 channels and, hence, the decrease in the Q-factor for the $25 \mathrm{GHz}$-spaced system is primarily due to the nonlinearities.

Table 3. Dispersions at the input and output of our transmission channel.

\begin{tabular}{cccc}
\hline \multicolumn{4}{c}{$25 \mathrm{GHz}, 40 \mathrm{Gbps}$ channel; frequency $189.1 \mathrm{THz}$} \\
\hline $\begin{array}{c}\text { Number of } \\
\text { channels }\end{array}$ & $\begin{array}{c}\text { Input disper- } \\
\text { sion, } 10^{5} \mathrm{ps} / \mathrm{nm}\end{array}$ & $\begin{array}{c}\text { Dispersion, } \\
10^{5} \mathrm{ps} / \mathrm{nm}\end{array}$ & $\begin{array}{c}\text { Output power, } \\
\mathrm{dBm}\end{array}$ \\
\hline 10 & -3.23 & -3.14 & 2.359 \\
16 & -3.698 & $11.89 \times 10^{6}$ & 1.1784 \\
32 & -4.772 & -4.6575 & -8.5 \\
96 & 0.556 & -4.8 & -7.587 \\
\hline
\end{tabular}

The effect of generation of idlers due to the FWM increases geometrically with increasing number of channels [19]. The situation becomes worse for the $25 \mathrm{GHz}$ system, if compared with the $50 \mathrm{GHz}$ system, due to increased probability of generated idlers which coincide with the transmitted-signal frequencies. The presence of dispersion decreases the efficiency of FWM-power transfer between the signal and the pump required for the FWM-based parametric amplification. 
This explains a widening gap between the Q-factor values obtained for the $25 \mathrm{GHz}$ and $50 \mathrm{GHz}$ systems with increasing number of channels (see Fig. 6).

The gain for the $25 \mathrm{GHz}$ system at $40 \mathrm{Gbps}$ shows a minimum $16.92 \mathrm{~dB}$ and a maximum 22.74 (see Fig. 7). This gives the gain ripple $5.82 \mathrm{~dB}$. No gain-compensation or gain-filtering techniques have been used and so the dispersion compensation is attributed entirely to the Raman fibre. This makes our Raman-parametric hybrid relatively cheap in achieving the flat gain.

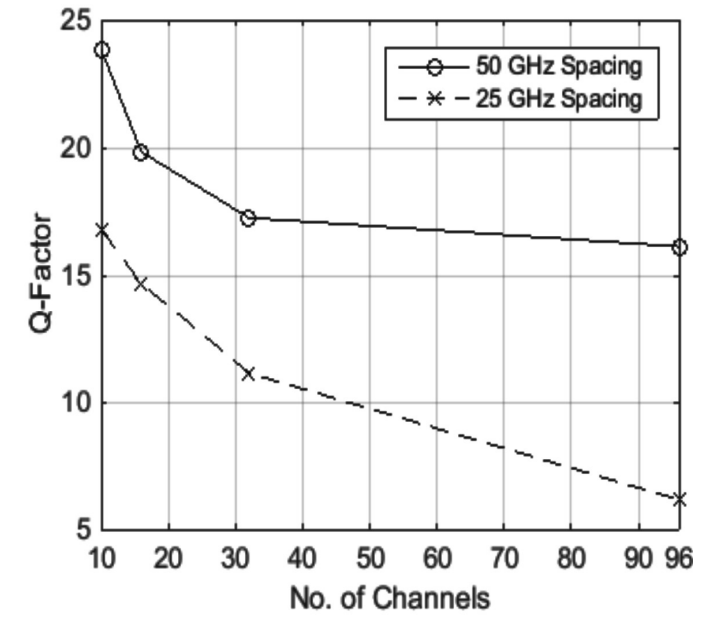

Fig. 6. Dependences of Q-factor on the channel number for the $25 \mathrm{GHz}$ - and $50 \mathrm{GHz}$-spaced systems.

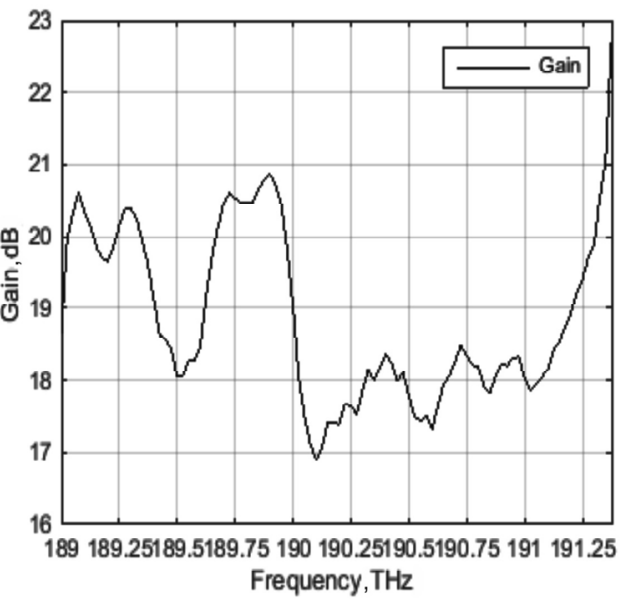

Fig. 7. Frequency dependence of gain for the $25 \mathrm{GHz}$ system at $40 \mathrm{Gbps}$.

Singh et al. [28] have regarded the influence of nonlinearities in the FWM fibre on the dispersion as an important contributing factor. Additionally, the dispersion at the input of transmission fibre is relatively high for this system, due to a large number of closely spaced channels. Either dynamic dispersion-compensation technique or gratings can be employed to achieve better results. This should reduce the dispersion and, hence, increase the efficiency of the FWM required for parametric amplification. Though decreasing duty cycle of the pulse can be of aid in this respect, the pulse-width effect becomes negligible at the data rates higher than $40 \mathrm{Gbps}$. This definitely requires a more detailed analysis of dispersion at $40 \mathrm{Gbps}$ and higher data rates with different modulation formats. However, we have demonstrated a clear possibility for the nonreturn-to-zero modulation-based high data-rate systems, using our Raman-FOPA cascade configuration. The primary focus of the current study is to design the hybrid amplifier for the DWDM systems with the flat gain enhanced with respect to the existing hybrid amplifiers, with employing no gain-compensation technique so as to reduce the cost of the system.

To compare the results demonstrated by our configuration with the data known for the recent L-band systems, we evaluate our system for the case of $187 \mathrm{THz}$ band at $10 \mathrm{Gbps}$, which has been studied in Refs. [29, 30]. This comparison testifies strong tunability and flexibility of the design suggested in the present work. Our system uses three pumps each of which has the power $350 \mathrm{~mW}$ at $10 \mathrm{Gbps}$, which is a quite low power. The optimized pump power is somewhere in between 100 and $250 \mathrm{~mW}$.

Our hybrid amplifier provides the highest gain larger than $14.1 \mathrm{~dB}$ at the L-band frequencies and the gain ripple less than $1.9 \mathrm{~dB}$, although no gain-flattening or optimization techniques are used. Our system exploits the inherent FWM nonlinearity in the multichannel system for enhancing performance via optical amplification. Moreover, it obtains wider system margins with increased net gains, due to a dispersion-compensated Raman amplifier. In Table 4 we compare 
some of the specific features of our hybrid amplifier with those typical for the other hybrid amplifiers for the L-band DWDM systems known from the literature.

Table 4. Comparison of our 10 Gbps hybrid amplifier with the other amplifiers known for the L-band.

\begin{tabular}{|c|c|c|c|}
\hline Parameter & $\begin{array}{c}\text { L-band Raman-EDFA } \\
\text { HOA [29] (2011) }\end{array}$ & $\begin{array}{c}\text { L-band Raman-EDFA- } \\
\text { DCF [30](2013) }\end{array}$ & $\begin{array}{c}\text { Raman-FOPA cascade } \\
\text { with dispersion } \\
\text { compensation } \\
\end{array}$ \\
\hline System & DWDM & DWDM & DWDM \\
\hline Band & $\mathrm{L}(186.7-190.95) \mathrm{THz}$ & L (187-190.975) THz & $\mathrm{L}(187-189.375) \mathrm{THz}$ \\
\hline Bandwidth & $35 \mathrm{~nm}$ & $24 \mathrm{~nm}$ & $20 \mathrm{~nm}$ \\
\hline $\begin{array}{l}\text { Number of } \\
\text { channels }\end{array}$ & 35 & 160 & 96 \\
\hline Gain & $>12 \mathrm{~dB}$ & $>10 \mathrm{~dB}$ & $>14.1 \mathrm{~dB}$ \\
\hline Ripple & $\sim 1.2 \mathrm{~dB}$ & $<4.5 \mathrm{~dB}$ & $1.89 \mathrm{~dB}$ \\
\hline Channel spacing & $125 \mathrm{GHz}$ & $25 \mathrm{GHz}$ & $25 \mathrm{GHz}$ \\
\hline Input power & $\begin{array}{c}0.001-0.01 \mathrm{~mW} \\
\text { per channel }\end{array}$ & $3 \mathrm{~mW}$ & $1 \mathrm{~mW}$ \\
\hline $\begin{array}{l}\text { Hybrid amplifier } \\
\text { used }\end{array}$ & Raman + EDFA & $\begin{array}{c}\text { Distributed Raman } \\
\text { amplifier }+ \\
\text { EDFA + DCF }\end{array}$ & Raman-DCF + FOPA \\
\hline Data rate & $10 \mathrm{Gbps}$ & $10 \mathrm{Gbps}$ & $10 \mathrm{Gbps}$ \\
\hline $\begin{array}{l}\text { Flattening } \\
\text { technique }\end{array}$ & Nil & Nil & Nil \\
\hline
\end{tabular}

Dispersion-compensated fibre is abbreviated as DCF and hybrid optical amplifier as HOA. Notation '+' (as in 'Raman + EDFA') implies a cascade, while 'Raman-DCF' denotes dispersion compensation in a Raman fibre.

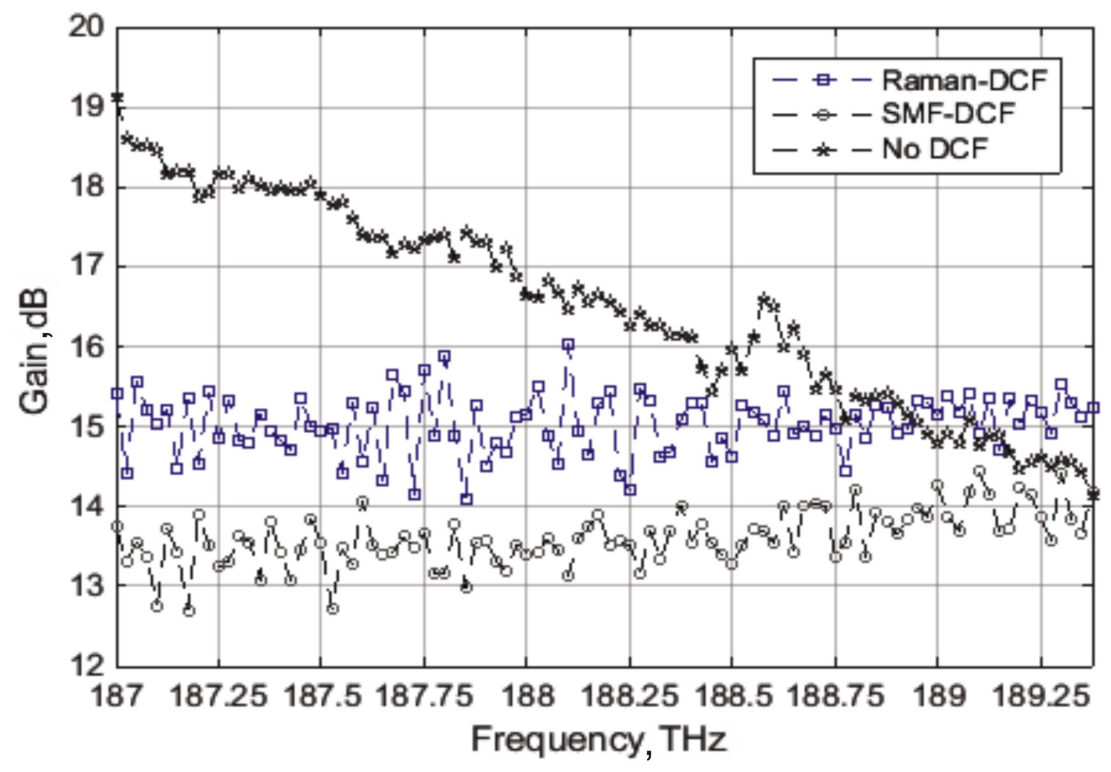

Fig. 8. Frequency dependence of gain obtained for a combination of single-mode fibre with dispersioncompensated fibre (SMF-DCF), a Raman-DCF system and no-DCF system. The results concern the 96channel system, the spacing $25 \mathrm{GHz}$, the rate $10 \mathrm{Gbps}$ and the band $187-189.375 \mathrm{THz}$. 
Fig. 8 illustrates the improvement achieved when the dispersion compensation is combined with the Raman amplification, as compared to the system with no dispersion compensation at all and the traditional system combining a dispersion-compensated fibre with a transmission fibre. The data indicated in blue in Fig. 8 shows that the gain for the Raman-FOPA cascade is the highest and the ripple is minimal. Also, the additional advantage of low-amplification noise in the FOPA makes the Raman-FOPA system favourable over the other hybrid optical amplifiers. Flexibility in choosing the pump powers across any communication band makes our RamanFOPA cascade preferable over the hybrid optical-amplifier configurations. Application of the Raman-FOPA hybrid has already been demonstrated for the cases of wideband amplification [12] and terabit-capacity DWDM systems with pump modulation [31,32]. This implies its suitability to the high-capacity DWDM systems. As a consequence, we have proposed a flat-broadband and tunable hybrid parametric amplifier based on intensity-modulated direct-detection system. It is free of disadvantages peculiar to the costly and complex coherent receivers required for advanced modulation formats suggested in Refs. [33-36].

\section{Conclusion}

The results obtained in the present work confirm feasibility of dispersion-compensated Raman fibreamplifier cascade with a single-pump FOPA for the narrow-spaced DWDM systems. The configuration of the Raman-FOPA cascade suggested by us offers the advantages of flexibility and wider and flatter gain over the other hybrid amplifiers known up to date. This is due to inherent tunability and wide-gain characteristics of the Raman amplifier and the FOPA, which can be complemented to achieve a flatter gain. Combining the dispersion compensation with the Raman fibre amplification offers enhanced gains and lower ripples if compared with the traditional dispersion-compensation techniques based upon dispersion-compensated fibres. The long-distance transmission capabilities of our dispersion-compensated Raman-amplifier cascade with the FOPA should be further explored and its tunability across different communication bands should be verified in practice. Since our cascade exploits the nonlinearities in the transmission fibre, the use of polycrystalline fibres with the nonlinearity coefficients larger than 50 in our hybrid amplifier should be further investigated with the aim of enhancing the performance of optical transmission systems.

\section{References}

1. Hansryd J, Andrekson PA, Westlund M, Li J, and Per-Olof Hedekvist, 2002. Fiber based optical parametric amplifiers and their applications. IEEE J. Sel. Top. Quant. Electron. 8: 506520.

2. Taghizadeh M, Kazem Tavassoly M, Hatami M and Pakarzadeh H, 2018. One-pump fiber optical parametric amplifiers: from the pulsed to the continuous wave operation. Opt. Eng. 57: 056103.

3. Imajuku W, Takada A and Yamabayashi Y, 2000. Inline coherent optical amplifier with noise figure lower than $3 \mathrm{~dB}$ quantum limit. IEEE Electron. Lett. 36: 63-64.

4. Jazayerifar M, Warm S, Elschner R, Kroushkov D, Sackey I, Meuer C, Schubert C and Petermann K, 2013. Performance evaluation of DWDM communication systems with fiber optical parametric amplifiers. IEEE J. Lightwave Technol. 31: 1454-1462.

5. Islam M, 2006. Raman amplifiers for telecommunications. IEEE J. Sel. Top. Quant. Electron. 8: $548-559$.

6. Liaw S, Ho K, Huang $\mathrm{C}$, Chen $\mathrm{W}$, Hsiao $\mathrm{Y}$ and Lai I, 2006. Investigate $\mathrm{C}+\mathrm{L}$ band EDFA/Raman amplifiers by using the same pump lasers. IEEE Joint Conference on

Ukr. J. Phys. Opt. 2020, Volume 21, Issue 1 
Information Sciences. Kaohsiung, Taiwan, October 8-11.

7. Lei Gordon and Marhic M, 2013. Performance investigation of a hybrid fiber optical parametric amplifier. Opt. Express. 21: 21932-21940.

8. Kidorf H, Rottwitt K, Nissov M, Ma M and Rabarijaona E, 1999. Pump Interactions in a 100$\mathrm{nm}$ bandwidth Raman amplifier. IEEE Photon. Technol. Lett. 11: 530-532.

9. Torounidis T, Andrekson P A and Olsson B, 2006. Fiber-optical parametric amplifier with 70dB gain. IEEE Photon. Technol. Lett. 18: 1194-1196.

10. Wang S and Wai P. Gain enhancement in hybrid fiber Raman/parametric amplifiers. CLEO Baltimore, MD, USA (2009).

11. Peiris S, Madamopoulos N, Antoniades N, Richards D, Ummy MA and Dorsinville R, 2014. Engineering an extended gain bandwidth hybrid Raman-optical parametric amplifier for next generation CWDM PON. J. Lightwave Technol. 32: 939-947.

12. Kaur Gagan, Kaur G and Sharma S, 2016. Multi-section optical parametric-Raman hybrid amplifier for Terabit + WDM systems. J. Mod. Opt. 63: 819-825.

13. Stephens M F C, Phillips I D, Rosa P, Harper P and Doran N J, 2015. Improved WDM performance of fibre optic parametric amplifier with Raman assisted pumping. Opt. Express. 23: 902-912.

14. Ummy M A, Arend M F, Leng L, Madamopoulos N and Dorsinville R, 2009. Extending the gain bandwidth of combined Raman-parametric fiber amplifiers using highly nonlinear fiber. IEEE J. Lightwave Technol. 27: 583-590.

15. Kaur Gagan, Kaur G and Sharma S, 2017. Performance optimization of broadband communication system using hybrid parametric amplifier. Int. J. Appl. Res. 12: 4484-4490.

16. Kaur Gaganpreet, 2020. Engineering flat gain tunable Raman-parametric hybrid L-band amplifier for narrow band multi-channel Terabits system. J. Opt. Comm. 41: 1-8.

17. Lewis S A E, Chrenikov S V and Taylor J R, 2000. Broadband high gain dispersion compensating Raman amplifier. IEEE Electron. Lett. 36: 1355-1356.

18. Hansen P B, Jacobovitz-Veselka G, Grüner-Nielsen L and Stentz A J, 1998. Raman amplification for loss compensation in dispersion compensating fiber modules. IEEE Electron. Lett. 34: 1136-1137.

19. Agrawal G. Non-linear fiber optics. London: Academic Press (1999), P. 316-324.

20. Fludger C R S, Handerek V and Mears R J, 2001. Pump to signal RIN transfer in Raman fibre amplifiers. Electron. Lett. 37: 15-17.

21. Gao M, Jiang C, Hu W, Zhang J and Wang J, 2007. The effect of phase mismatch on twopump fiber optical parametrical amplifier. Opt. Laser Technol. 39: 327-332.

22. Rotich E, 2011. Factors affecting dual pump fiber optical parametric amplification gain. Proc. for Sustainable Research and Innovation Conference, 3.

23. Wen $\mathrm{Y}$, Zhu $\mathrm{F}$ and Bai $\mathrm{Y}, 2015$. Experimental investigation on dispersion tolerance of 8x53.2Gbps NRZ for $400 \mathrm{GbE} 2 \mathrm{~km}$ and $10 \mathrm{~km}$ PMD. Huawei Technologies. US R\&D Center, IEEE802.3bs 400GbE Task Force Berlin Plenary Meeting.

24. Lavery D, Liu S, Jeong Y, Nilsson J, Petropoulos P, Bayvel P and Savory S J. Realizing high sensitivity at 40Gbit/s and 100Gbit/s. 2012. IEEE Optical Fiber Communication Conf. 1-3.

25. Doerr C R, Winzer P J, Raybon G, Buhl L L, Cappuzzo M A, Wong-Foy A, Chen E Y, Gomez L T and Duelk M, 2005. 2000-km WDM transmission of $10 \times 107-\mathrm{Gb} / \mathrm{s}$ RZ-DQPSK. $31^{\text {st }}$ European Conference on Optical Communication, U. K., Paper Th. 4.2.1.

26. Turkiewicz J P, Tangdiongga E, Lehmann G, Rohde H, Schairer W, Zhou Y R, Sikora E S R, 
Lord A, Payne D B, Khoe GD and H de Waardt, 2005. $160 \mathrm{~Gb} / \mathrm{s}$ OTDM networking using deployed fiber. J. Lightwave Technol. 23: 225-235.

27. Daikoku M, Morita I, Taga H, Tanaka H, Kawanishi T, Sakamoto T, Miyazaki T and Fujita T, 2007. 100-Gb/s DQPSK transmission experiment without OTDM for 100Gbit Ethernet transport. IEEE J. Lightwave Technol. 25: 139-146.

28. Singh A, Sharma A K and Kamal T S, 2007. Four-wave mixing analysis in WDM optical communication systems with higher-order dispersion. Optik. 119: 788-792.

29. Abu Bakar M H, Abas A F, Mokhtar M, Mohamad H and Mahdi M A, 2011. Utilization of stimulated Raman scattering as secondary pump on hybrid remotely pump L-band Raman/erbium doped fiber amplifier. J. Laser Phys. 21: 722-728.

30. Singh S and Kaler R, 2013. Flat-gain L-band Raman-EDFA hybrid optical amplifier for dense wavelength division multiplexed system. IEEE Photon. Technol. Lett. 25: 250-252.

31. Kaur Gagan, Kaur G and Sharma S, 2015. Enhanced gain using Raman-FOPA hybrid amplifier for L-Band 96 X 100 Gbps DWDM systems. IEEE Xplore - Next Generation Computing Technologies. UPES, Dehradun, India, $4-5^{\text {th }}$ September.

32. Kaur G, Sharma S and Kaur G, 2016. Novel Raman parametric hybrid L-band amplifier with four-wave mixing suppressed pump for Terabits dense wavelength division multiplexed systems. Adv. Opt. Technol. 2016: ID 6148974. 8 p.

33. Ali F, Khan Y and Qureshi S S, 2019. Transmission comparison of 16 X100 Gbps dense wavelength division multiplexed long haul optical networks at different advance modulation formats under the influence of non-linear impairments. J. Opt. Comm. (at press).

34. Abd H J, Jaber A H and Al-Hayder A A, 2018. Effectiveness of modulation formats to nonlinear effects in optical fiber transmission systems under $160 \mathrm{~Gb} / \mathrm{s}$ data rate. Prog. Electron. Res. 78: 9-12.

35. Olsson SL, Corcoran B, Lundstrom C, Eriksson T A, Karlsson M and Andrekson P A, 2015. Phase sensitive amplified transmission links for improved sensitivity and nonlinearity tolerance. IEEE J. Lightwave Technol. 33: 710-721.

36. Salgals T, Kurbatska I, Spolitis S, Bobrovs V and Ivanovs G, 2019. Research of M-PAM and duobinary modulation formats for use in high-speed WDM-PON systems. Intech. Open Book - Telecommunication systems - principles and applications of wireless optical technologies.

Kaur G., Kaur Gurmeet and Sharma S. 2020. New dispersion-compensated Raman-amplifier cascade with a single-pump parametric amplifier for dense wavelength-division multiplexing. Ukr.J.Phys.Opt. 21: 35 - 46. doi: 10.3116/16091833/21/1/35/2020

\begin{abstract}
Анотація. У иій роботі раманівський підсилювач з компенсаиією дисперсії введено в каскад із параметричним підсилювачем з єдиним нагнітанням для створення мультиплексованої системи зі щільним розділенням по довжині хвилі (МЩРХ). Ця гібридна система виявляє рівномірне підсилення в усій L-смузі. Даний гібрид було досліджено для 96-канальної системи з параметрами 25 ГГи і 40 Гбіт/с у діапазоні від 189 до 191,375 ТГи. Результати засвідчують можливість коефіщієнта підсилення, вищого за 16,9 дБ, і пульсаиії підсилення, меншої за 5,82 дБ, навіть якщо не застосована жодна методика вирівнювання підсилення. Новизна нашої конструкції полягає в поєднанні компенсаиії дисперсї̈ з підсиленням сигналу за допомогою волоконного підсилювача на волокні значної довжсини, з наступним параметричним підсиленням, реалізованим на окремому нелінійному волокні малої довжини. За умови швидкості передавання даних 10 Гбіт/с пульсаиія підсилення є низькою (1,9 дБ) без будь-яких заходів для компенсаиії підсилення. Відномення оптичного сигналу та
\end{abstract}

Ukr. J. Phys. Opt. 2020, Volume 21, Issue 1 
шуму, більше за 18 дБ, $i$ рівномірність коефіцієнта підсилення підтверджують можливість використання такого раманівського волоконно-оптичного параметричного підсилювача як регульованого підсилювача з широкими межами коефіцієнта підсилення в майбутніх системах МЩРХ для далекого зв'язку. Ми порівняли результати, одержані для нашої системи, з даними для інших оптичних підсилювачів в L-смузi, розроблених недавно. Порівняння засвідчує, щзо наш підсилювач найкращчий серед усіх аналогів. 